\title{
Grensoverschrijdende kwalificatieproblematiek
}

Citation for published version (APA):

Didden, B. M. M. (2019). Grensoverschrijdende kwalificatieproblematiek: Tussen sociale zekerheid en aanvullende pensioen. [, Maastricht University]. ProefschriftMaken. https://doi.org/10.26481/dis.20191108bd

Document status and date:

Published: 01/01/2019

DOI:

10.26481/dis.20191108bd

Document Version:

Publisher's PDF, also known as Version of record

\section{Please check the document version of this publication:}

- A submitted manuscript is the version of the article upon submission and before peer-review. There can be important differences between the submitted version and the official published version of record.

People interested in the research are advised to contact the author for the final version of the publication, or visit the DOI to the publisher's website.

- The final author version and the galley proof are versions of the publication after peer review.

- The final published version features the final layout of the paper including the volume, issue and page numbers.

Link to publication

\footnotetext{
General rights rights.

- You may freely distribute the URL identifying the publication in the public portal. please follow below link for the End User Agreement:

www.umlib.nl/taverne-license

Take down policy

If you believe that this document breaches copyright please contact us at:

repository@maastrichtuniversity.nl

providing details and we will investigate your claim.
}

Copyright and moral rights for the publications made accessible in the public portal are retained by the authors and/or other copyright owners and it is a condition of accessing publications that users recognise and abide by the legal requirements associated with these

- Users may download and print one copy of any publication from the public portal for the purpose of private study or research.

- You may not further distribute the material or use it for any profit-making activity or commercial gain

If the publication is distributed under the terms of Article $25 \mathrm{fa}$ of the Dutch Copyright Act, indicated by the "Taverne" license above, 


\title{
Stellingen behorende bij het proefschrift
}

\section{'Grensoverschrijdende kwalificatieproblematiek: tussen sociale zekerheid en aanvullend pensioen'}

\author{
Bastiaan M.M. Didden
}

1. De vormgeving van de sociale zekerheids- en pensioenstelsels van de EU-lidstaten wordt gekenmerkt door een nationale focus. Deze vormgeving en de (faciliterende) rol die de fiscaliteit hierbij speelt, zijn van invloed op de wijze waarop wordt omgegaan met de grensoverschrijdende pensioenkwalificatieproblematiek. Met de door mij voorgestelde keuze voor toepassing van het beginsel van wederzijdse erkenning kan gekomen worden tot 'meer eenheid in verscheidenheid' bij de kwalificatie van buitenlands pensioen door de EUlidstaten.

2. De pensioenkwalificatieproblemen die centraal staan in dit onderzoek, 'raken' de inhoud van de pensioenpremiebepaling in een belastingverdrag. Met het oog op een integrale en adequate oplossing van deze kwalificatieproblemen moet de pensioenpremiebepaling als basis dienen voor de nadere uitwerking in een pensioenkwalificatieprotocol.

3. De keuze voor de wederzijdse erkenning van buitenlands pensioen is een keuze voor arbeidsimportneutraliteit en toepassing van het werkstaatbeginsel. 
4. EU-lidstaten moeten overgaan tot een nadere inventarisatie van de financieringswijze van de sociale zekerheid. Hierbij dient in het bijzonder oog te zijn voor het deel van de belastingen dat is bestemd voor de financiering van de sociale zekerheid. In de EU-lidstaat waar de mobiele werknemer belastingplichtig is voor zijn wereldinkomen, moet de mobiele werknemer op grond van Verordening nr. 883/2004 worden vrijgesteld van de plicht om dit 'sociaal gelabelde' deel van de belastingen te voldoen. Alleen zo kan worden voorkomen dat een mobiele werknemer wordt geconfronteerd met een dubbele economische premieheffing.

5. Hoewel de term 'kwalificatie' wellicht anders doet vermoeden, behelst het komen tot een oplossing voor de pensioenkwalificatieproblematiek zo veel meer dan het alleen zoeken naar definities. Het gaat bovenal om het doorgronden van de concepten en achterliggende ideeën die ten grondslag liggen aan de nationale, beleidsmatige keuzes die gemaakt zijn (en worden) bij de fiscale behandeling van pensioen.

6. Bij de totstandkoming van grensoverschrijdend pensioenbeleid moet een principle-based approach worden aangelegd; hetgeen inhoudt dat beleidsmakers een pensioenambitie in termen van adequaat pensioeninkomen moeten formuleren. 
7. Grensverleggende oplossingen voor mobiele werknemers vereisen dat beleidsmakers ook over hun eigen expertisegrenzen durven en moeten kijken; niet alleen op nationaal niveau, ook op Europees en internationaal niveau is deze 'durf' en samenwerking noodzakelijk.

8. De toenemende keuze door de EU-lidstaten voor een bronstaatheffing bij grensoverschrijdende pensioenuitkeringen vereist ook dat de lidstaten inzicht hebben in de grensoverschrijdende pensioenopbouw van een individu. De ontwikkeling van een Europees Pensioenregister is dan ook toe te juichen, mits niet alleen inzicht wordt geboden in het door een individu opgebouwde pensioen, maar ook kan worden vastgesteld in welke lidstaat en voor welke tijdsduur een pensioenregeling fiscaal is gefaciliteerd: track \& trace the tax facilitated pensions.

9. Onderhavig onderzoek kan binnen de Europese Unie als Witboek / roadmap fungeren. Niet alleen omdat het onderzoek naadloos aansluit bij het huidige streven van de Europese beleidsmakers naar het bevorderen van de grensoverschrijdende arbeidsmobiliteit en pensioeninkomen, maar ook vanwege het feit dat aan de voorgestelde oplossingsrichtingen een internationaal aanvaard toetsingskader en rechtsvergelijkend onderzoek ten grondslag ligt. 